\title{
Discriminate Analyses of Motivators and Obstacles on Youth Entrepreneurial Intention
}

\author{
Ng Kim-Soon ${ }^{1}$, Abd Rahman Ahmad ${ }^{1}$, Abu Zar Md Saberi ${ }^{1} \&$ Huam Hon Tat ${ }^{2}$ \\ ${ }^{1}$ Faculty of Technology Management and Business, Universiti Tun Hussein Onn Malaysia, Batu Pahat, Johor, \\ Malaysia \\ ${ }^{2}$ Faculty of Business, Management and Social Sciences, Quest International University Perak, Perak, Malaysia \\ Correspondence: Ng Kim-Soon, Faculty of Technology Management and Business, Universiti Tun Hussein Onn \\ Malaysia, 86400 Batu Pahat, Johor, Malaysia. Tel: 60-7-453-3960. E-mail: ksng@uthm.edu.my
}

Received: July 31, 2013 Accepted: October 8, 2013 Online Published: November 29, 2013

doi:10.5539/ass.v9n17p53

URL: http://dx.doi.org/10.5539/ass.v9n17p53

\begin{abstract}
This study investigates the motivators and obstacles to youth entrepreneurship with entrepreneurial intention. Data were collected through 150 self-administered questionnaires distributed to 150 youths. The motivators and obstacles of youth entrepreneurial adapted from previous studies formed part of the questionnaire and were used to discriminate using SPSS software on youth entrepreneurial intentions. It is found that the main motivators for youth intention to become an entrepreneur are that they need to be really serious to start and own a business $(p<0.001)$. On the other hand, youth who are not determined enough to be an entrepreneur is unlikely to become one $(\mathrm{p}<0.05)$. This implies that youths who are really serious to start and own a business as would be entrepreneurs can be identified and targeted to develop through government entrepreneurship interventions initiatives.
\end{abstract}

Keywords: entrepreneurship intention, entrepreneurial motivators, entrepreneurial obstacles

\section{Introduction}

Entrepreneurship is vital to economic growth, wealth and job creation (Fiar \& Meyer, 2003). It is not a new trend in Malaysia. Youngsters have been working as business entreprenuers in many centuries. Malaysian government has been providing tax incentives, business advisory loan and funding to support and groom young entrepreneurs Studies on youth entreprenuership will provide the awareness to youngster on the importance of participating in entrepreneurship since young, encouraged the education ministry to provide the entrepreneurship subject in curriculum to youth that are inclined to entrepreneurship in business. This enhances interest, nurture and nuture the innovative mindset of the individual towards entrepreneurship field. Literature reviews indicated a lacking of research specifically that focused on youth entrepreneurship, and that opportunities and constraints for youth entrepreneurship can differ regionally (Ellis \& Williams, 2011).

\section{Literature Review}

Entrepreneurship has been defined as a dynamic interaction of entrepreneurial attitudes, activity, and aspiration that vary across stages of economic development (Acs \& Szerb, 2009). Research by Bates (1995) reported lower level of self-employment preference for female gender comparing to male. Levesque and Minniti (2005) argued that when individuals are older, wage-employment becomes more attractive than self-employment and literature reported that younger individuals are more likely to start a new business. Investigation by Matthews and Moser (1996) reported that women tend to start a business for the first time at an older age. Verheul, Thurik and Grilo (2006) reported that there is no significant relationship between education levels and self-employment.

\subsection{Entrepreneurial Intention}

Entrepreneurial intention is reflected in the conviction of the person to start up new business. The intention is based on the certain attitude in that person. Attitude is mediator to affect the entrepreneurship intention. Choo and Wong (2009) added that intention is a main predictor to predict the behavior of the entrepreneur and the self-commitment of doing the business enabling significance impact to form the entrepreneurial intention as it is not an activity. However, it takes a long-term process to develop it. Entrepreneurial intention is central to comprehend a holistic entrepreneurship process embedded in new organization (Van Gelderen, Brand, Van Praag, 
Bodewes \& Van Gils, 2008). If the individual have the intention and tendency to start up new business is not enough to achieve the objective, they must have adoption behavior then the objective will be easy to achieve. Pihie (2009) revealed that the intention behavior can be the determinate factor to predict the human behavior. Ajzen's Theory of Planned Behavior the most defining characteristic of entrepreneurship is the intention to start a business. He posited that any planned behavior is best predicted from the intention to perform that behavior, and the intention to perform the given behavior is influenced by the desirability and feasibility of the behavior, and individual background factors (Ajzen, 1991).

\subsection{Entrepreneurial Motivators}

According to Ashley-Cotleur, King, and Solomon (2009), there are a few motivators to drive someone be an entrepreneur and they categorized it into (1) demographic variable, (2) attitude, value or psychological factor. Demographic variable will affect entrepreneurship activity such as gender (Kolvereid, 1993; Matthews \& Moser, 1995). Crant (1996) found that the family background is motivator as well. For example, men who are growing in the family of entrepreneurship background have the high tendency to follow his family's footstep, start up new business by their own. Role model is also the significance motivator of driving someone to start up new business (Birley \& Westley, 1994). Their parent has the tendency to be their children's mentor if they have the working experience and to guide them to start up new business (Matthews \& Moser, 1995).

Robichaud, McGraw and Roger (2001) mentioned that there are 4 kinds of categories: (1) extrinsic reward, (2) autonomy, (3) intrinsic reward, and (4) family safety. The differences of the intrinsic and extrinsic reward are in term of motive. Intrinsic reward is related to the self-compliance and grows. It more on drive on the enjoyment in task itself, and intrinsic motivator is more on want to see their skills are improved and enjoy in the self-fulfillment. In other way is extrinsic motivation is perform a task is because to gain the outcome and result from outside, for example participate the competition is just want to enjoy the fulfillment in the extrinsic reward, such as trophy, hamper and etc.

\subsection{Entrepreneurial Obstacles}

The first obstacle of the youth participate the entrepreneurship activity is lacking of the financial support. Pretorius and Shaw (2004) showed that majority of the entrepreneurship in the South Africa failed due to not enough capital and lack of resource. The second barrier is that youth are not willing to take risk. They are afraid of failure and cannot stand in the test, will try to avoid explore new knowledge or idea to improve their current situation. It is hard for them to compete with other successful entrepreneurs who are daring to breakthrough in the competitive market. Papulova and Makros (2007) found that majority of the youth lack management skills especially the long term skill technique in the entrepreneurship.

\section{Methodology}

Data for this study were collected by convenient sampling method using self-administered questionnaire distributed to 150 youths living in Batu Pahat, a town located at Johor, Malaysia. The independent variables are the motivator and obstacle on the interest of the youth towards entrepreneurship. Respondent rated on a five point scale, the level of agreement of motivators or obstacles affecting their interest towards entrepreneurship. The dependent variables are the dichotomous questions of youth entrepreneurial intentions. The respondent ticked either a "yes" or "no" on each of the items of youth entrepreneurship intention questions. The motivator and obstacle of entrepreneurship intention measures, and the dichotomous measures of entrepreneurship intention items were adapted and adopted from those used by Solesvik, Westhead, Kolveried and Matlay (2012), Samuel, Ernest, and Awuah (2013), and Fatoki and Olufunso (2012). Cronbach's alpha was used to test the reliability of these measurements. The Cronbach's alpha for the 20 items on motivator of entrepreneurship is 0.84 and the 20 items of obstacles to youth entrepreneurship is 0.86 . Reliability scores greater than 0.70 are considered acceptable.

\section{Findings and Discussions}

Table 1 tabulates the profile of the respondents. The total number of respondents is 150 people. There are equal numbers of male and female, a total of $75(50 \%)$ people each. Their age varies from 21 to 29 years, where 108 (72\%) people are 21 years of age to 25 , and $42(28 \%)$ are older than 26 to 29 year of age. They are comprised of 3 main races of the populations, where $97(64.7 \%)$ are Malay, $36(24.0 \%)$ are Chinese, 14 (9.3\%) are Indian with the remaining $3(2.0 \%)$ from the other races. Thus, the influence gender, age and race factors are controlled in this study and that the population is the range of the youth.

Table 2 tabulates the result of discriminate analysis of entrepreneurial motivations on intentions. From this table, it is observed that the statement "I have thought seriously to start my own business after completing my 
education" of entrepreneurship intentions indicated a significant F-Test value at $\mathrm{p}=0.001$ and "I want to be my own boss" indicated a significant F-test value of $\mathrm{p}<0.001$. This implies that the said motivators for youth intention to become an entrepreneur are that they need to be really serious to start and own a business.

Table 1. Profile of the respondents $(\mathrm{N}=150)$

\begin{tabular}{lllll}
\hline S/N & Demographic & Categories & Frequency & $(\%)$ \\
\hline \multirow{2}{*}{ 1. Gender } & \multirow{2}{*}{ Age (years) } & a. Male & 75 & 50 \\
& & b. Female & 75 & 50 \\
2. & a. 21 to $=<25$ & 108 & 72 \\
& & b. $>26$ to $=<29$ & 42 & 28 \\
& a. Malay & 97 & 64.7 \\
3. & Race & b. Chinese & 36 & 24.0 \\
& & c. Indian & 14 & 9.3 \\
& & d. Others & 3 & 2.0 \\
& \multirow{2}{*}{ Education } & a. Secondary School & 22 & 14.7 \\
& & b. Diploma & 4 & 2.7 \\
\hline
\end{tabular}

Table 2. Discriminate analysis of entrepreneurial motivations on intentions

\begin{tabular}{llll}
\hline S/N & Entrepreneurship Intentions (Dependent Variables) & F Value & $\begin{array}{c}\text { Significant value } \\
\text { of F-test }\end{array}$ \\
\hline 1. & My professional goal is to become an entrepreneur & .058 & .809 \\
2. $\quad$ I prefer to be an entrepreneur rather than to be an employee in a & .000 & .994 \\
3. $\quad$ I ampany prepared to do anything to be an entrepreneur & 1.563 & .213 \\
4. $\quad$ I'll put every effort to start and run my own business & .286 & .593 \\
5. I have thought seriously to start my own business after completing & 10.663 & $\mathbf{. 0 0 1}$ \\
6. $\quad$ I hy education & .072 & .788 \\
7. I'm determined to create a firm in the future & .300 & .585 \\
8. I want to be my own boss & 15.633 & $\mathbf{. 0 0 0}$ \\
9. I will start my business in the next five years & .605 & .438 \\
\hline
\end{tabular}

Table 3 tabulates the result of discriminate analysis of entrepreneurial obstacles on intentions. From this table, it is observed that the statement requesting the respondents to indicate whether they will start their business in the next five years indicated significant value of $F$ Test at $p<0.05$. It implies that youth who are not determined enough to be an entrepreneur is unlikely to become one.

These findings are in line with the behavioral theory posited by Ajzen (1991). It is about youth conviction to start up new business and own a business that will lead to business venture. It is about planned behavior and the serious thought to own and become a boss are as a result of to perform that behavior, and the intention to perform the given behavior is influenced by the desirability and feasibility of the owning a business. Praag and Ophem (1995) argued that insight into the individual determinants of the willingness and opportunity to become. 
Table 3. Discriminate analysis of entrepreneurial obstacles on intentions

\begin{tabular}{llll}
\hline S/N & Entrepreneurship Intention (Dependent Variables) & F Value & $\begin{array}{l}\text { Significant value } \\
\text { of F-test }\end{array}$ \\
\hline 1. & My professional goal is to become an entrepreneur & .088 & .767 \\
2. & $\begin{array}{l}\text { I prefer to be an entrepreneur rather than to be an employee in a } \\
\text { company }\end{array}$ & .909 & .342 \\
3. & I am prepared to do anything to be an entrepreneur & .087 & .769 \\
4. & I'll put every effort to start and run my own business & .800 & .373 \\
5. $\quad$ I have thought seriously to start my own business after completing my & 1.906 & .169 \\
6. $\quad$ I have a strong intention to start a business someday & 2.816 & .095 \\
7. & I'm determined to create a firm in the future & .619 & .433 \\
8. & I want to be my own boss & .339 & .561 \\
9. & I will start my business in the next five years & 5.065 & .026 \\
\hline
\end{tabular}

Self-employed is important to identify would be entrepreneurs to be targeted to develop them as entrepreneur through government assistance initiatives. Government agencies and different types of interventions could be offered. These include training, information, advisory, consultancy, financial, and vendor programmes. Entrepreneurship is a serious field of research work should be based on economic and management theory. As mentioned in the introduction, different contexts require tailored approaches to suit the respective needs of the individual concerned. Future researcher need to investigate from multi-level and wide time frame perspectives.

\section{Conclusion}

It is found that the main motivators for youth intention to become an entrepreneur are that they need to be really serious to start and own a business. Youth who are not determined enough to be an entrepreneur is unlikely to become one. For efficient entrepreneur development programme, youths who are really serious to start and own a business as would be entrepreneurs can be identified and targeted to develop through government entrepreneurship interventions initiatives.

\section{References}

Acs, Z. J., \& Szerb, L. (2009). The Global Entrepreneurship Index (GEINDEX). Foundations and Trends in Entrepreneurship, 5, 341-435. http://dx.doi.org/10.1561/0300000027

Ajzen, I. (1991). The theory of planned behavior. Organizational Behavior and Human Decision Processes, 50 , 179-211. http://dx.doi.org/10.1016/0749-5978(91)90020-T

Ashley-Cotleur, C., King, S., \& Solomon, G. (2009). Parental and gender influences on entrepreneurial intentions, motivations and attitudes. George Washington University.

Bates, T. (1995). Self-employment entry across industry groups. Journal of Business Venturing, 10, 143-156. http://dx.doi.org/10.1016/0883-9026(94)00018-P

Birley, S., \& Westhead, P. (1994). A taxonomy of business start-up: reasons and their impact on firm growth and size. Journal of Business Venturing, 9, 7-31. http://dx.doi.org/10.1016/0883-9026(94)90024-8

Choo, S., \& Wong, M. (2009). Entrepreneurial intention: triggers and barriers to new venture creations in Singapore. Singapore Management Review, 28(2), 47-64.

Crant, M. (1996). The proactive personality scale as a predictor of entrepreneurial intentions. Journal of Small Business Management, 5, 131-142.

Ellis, K., \& Williams, C. (2011). Maximising impact of youth entrepreneurship support in different contexts-Background report, framework and toolkit for consultation. Overseas Development Institute, 111 Westminster Bridge Road, London SE1 7JD, UK.

Fatoki, O., \& Patswawairi, T. (2012). The Motivations and Obstacles to Immigrant Entrepreneurship in South Africa. University of Johannesburg. South Africa Journal of Social Science, 32(2), 133-142.

Fiar, J. H., \& Meyer, M. H. (2003). Entrepreneurship and Start-Ups in the Boston Region: Factors Differentiating 
High-Growth Ventures from Micro-Ventures. Small Business Economics, 21, 145-152. http://dx.doi.org/10.1023/A:1025045828202

Kolvereid, L. (1996). Prediction of employment status choice intentions. Entrepreneurship Theory and Practice, 20(3), 47-56.

Levesque, M., \& Minniti, M. (2006). The effect of aging on entrepreneurial behavior. Journal of Business Venturing, 21(2), 177-194. http://dx.doi.org/10.1016/j.jbusvent.2005.04.003

Matthews, C. H., \& Moser, S. B. (1995). Family background and gender: implications for interest in small firm $\begin{array}{llll}\text { ownership. Entrepreneurship and Regional Development, } & \text { 7(4), 365-377. }\end{array}$ http://dx.doi.org/10.1080/08985629500000023

Matthews, C. H., \& Moser, S. B. (1996). A longitudinal investigation of the impact of family background and gender on interest in small firm ownership. Journal of Small Business Management, 34(2), 29-43.

Papulova, Z., \& Makros, M. (2007). Importance of managerial skills and knowledge in management of small entrepreneurs. Retrieved from http://docs.google.com/gview?a=v\&q=cache:72zbAzSb_icJ:www.gcasa.com/PDF/PapulovMokros.pdf + ma nagerial+skills + as $+\mathrm{a}+$ barrier + to + graduate + entrepreneurship\&hl=en\&gl=za

Pihie, Z. (2009). Entrepreneurship as a career choice: an analysis of entrepreneurial self-efficacy and intentions of university students. European Journal of Social Sciences, 9(2), 338-349.

Praag, C. M. V., \& Ophem, H. V. (1995). Determinants of the willingness and opportunity to start as an entrepreneur. Kyklos, 48, 513-540. http://dx.doi.org/10.1111/j.1467-6435.1995.tb01282.x

Pretorius, C., \& Shaw, P. (2008). Entrepreneurship education on South Africa. Retrieved June 1, 2009, from http://www.emeraldinsight.com/Insight/viewContentItem.do?contentType=Article\&hdAction=Inkhtml\&con tentId $=1562338$

Robichaud, Y., McGraw, E., \& Roger, A. (2001). Toward the development of a measuring instrument for entrepreneurial motivation. Journal of Developmental Entrepreneurship.

Samuel, Y. A., Ernest, K., \& Awuah, J. B. (2013). An Assessment of Entrepreneurship Intention among Sunyani Polytechnic Marketing Students. International Review of Management and Marketing, 3(1), 37-49.

Schoof, U. (2006). Stimulating Youth Entrepreneurship: Barriers and incentives to enterprise start-ups by young people. SEED Working Paper No. 76.

Solesvik, M. Z., Westhead, P., Kolveried, L., \& Matlay, H. (2012). Student intentions to become self-employed: The Ukrainian Context. Journal of Small Business and Enterprise Development, 19(3), 441-460. http://dx.doi.org/10.1108/14626001211250153

Van Gelderen, M., Brand, M., Van Praag, M., Bodewes, W., \& Van Gils, A. (2008). Explaining entrepreneurial intentions by means of the theory of planned behaviour. Career Development International, 13(6), 538-559. http://dx.doi.org/10.1108/13620430810901688

Verheul, I., Thurik, R., \& Grilo, I. (2006). Determinants of self-employment preference and realization of women and men in Europe and the United States. Scientific Analysis of Entrepreneurship and SMEs, SCALES-paper N200513.

\section{Copyrights}

Copyright for this article is retained by the author(s), with first publication rights granted to the journal.

This is an open-access article distributed under the terms and conditions of the Creative Commons Attribution license (http://creativecommons.org/licenses/by/3.0/). 